\title{
ATMOSPHERIC NITROGEN AND PHOSPHORUS LOADI NG TO HARP LAKE, ONTARIO, CANADA
}

\author{
June, 1977
}

The Honourable George R McCague, 
Copyright Provisions and Restrictions on Copying:

This Ontario Ministry of the Environment work is protected by Crown copyright (unless otherwise indicated), which is held by the Queen's Printer for Ontario. It may be reproduced for non-commercial purposes if credit is given and Crown copyright is acknowledged.

It may not be reproduced, in all or in part, part, for any commercial purpose except under a licence from the Queen's Printer for Ontario.

For information on reproducing Government of Ontario works, please contact Service Ontario Publications at copyright@ontario.ca 


\section{ATMOSPHERIC NITROGEN AND PHOSPHORUS LOADI NG TO HARP LAKE, ONTARIO, CANADA}

Kenneth H. Nicholls and Charles M. Cox

Limnology and Toxicity Section

Water Resources Branch

Ontario Ministry of the Environment

Box 213, Rexdale, Ontario, Canada, M9W 5L1

June, 1977 


\section{SUMMARY AND CONCLUSI ONS}

Nitrogen and phosphorus in precipitation and dry fallout (aeolian sources), as well as the $\mathrm{pH}$ of rainfall were measured over Harp Lake in Ontario during 1974. Weighted mean concentrations of total $\mathrm{N}$ and total $\mathrm{P}$ during the ice-free period of collection were $1.91 \mathrm{mg} \mathrm{N} / \mathrm{L}$ and $0.105 \mathrm{mg} \mathrm{P} / \mathrm{L}$. Winter concentrations of total N were similar but total $P$ concentrations were much lower averaging $0.018 \mathrm{mg} / \mathrm{L}$ in snow-ice (frozen precipitation) and $0.013 \mathrm{mg} / \mathrm{L}$ in fresh snow.

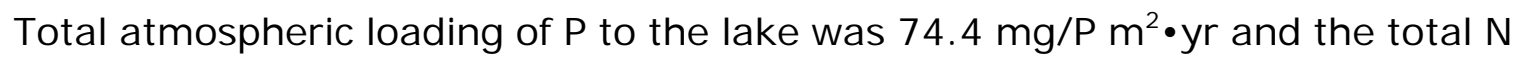
loading was $1600 \mathrm{mg} \mathrm{N} / \mathrm{m}^{2} \bullet \mathrm{yr}$. About $52 \%$ or $39.0 \mathrm{mg} \mathrm{P} / \mathrm{m}^{2} \bullet \mathrm{yr}$ of the total P loading from the atmosphere was as total dissolved $P(0.22 \mu \mathrm{m}$ filtrate) and $28 \%$ or $20.6 \mathrm{mg}$ $\mathrm{P} / \mathrm{m}^{2} \cdot \mathrm{yr}$ of the total $\mathrm{P}$ loading was as dissolved reactive $\mathrm{P}$ ("orthophosphate" - $\mathrm{P}$ ). Dissolved inorganic $\mathrm{N}$ loading at $1010 \mathrm{mg} \mathrm{N} / \mathrm{m}^{2} \cdot \mathrm{yr}$ comprised about $63 \%$ of the total $\mathrm{N}$ loading from the atmosphere. Pollen, from a variety of trees surrounding the lake, contributed about $20 \%$ of the total $P$ input.

It is conceivable that shallow ponds with low hydraulic loads (ie. those potholes on Ontario's Precambrian Shield with only intermittent inflows) could achieve eutrophic states resulting primarily from atmospheric inputs of nutrients. It is significant that a substantial portion of the total atmospheric nutrient load is in dissolved inorganic form and hence, is readily available for aquatic plants and algae.

The $\mathrm{pH}$ of rainfall samples ranged from 3.2 to 5.1 with a median value of 3.9 ( $\mathrm{n}$ $=14$ ). Industrial contamination of the atmosphere with oxides of nitrogen and sulphur is suggested. 


\section{NTRODUCTI ON}

There are few comprehensive and recent data on aeolian loading of nutrients to lakes (reviewed by Uttormark 1975). To be reliable, accurate calculations of nutrient budgets for lakes depend upon knowledge of nutrients supplied to lakes from the atmosphere (Dillon and Rigler 1975). Recent studies in Ontario (Dillon 1974; Gomolka 1975) have suggested that aeolian phosphorus loading may be a significant portion of the total phosphorus supplied to lakes from natural sources.

During a 1973-1974 limnological investigation of lakes in Ontario's Precambrian Shield (Nicholls 1976) several components of the nutrient budgets were determined. This paper reports on the atmospheric loading of $\mathrm{N}$ and $\mathrm{P}$ to Harp Lake.

\section{METHODS}

The rainfall collector (Fig. 1) was constructed of wood and painted on the exterior with marine enamel. The collecting surface was covered with fiberglass resin. The collector was installed on a rocky shoal approximately $50 \mathrm{~m}$ off the northwestern shore of Harp Lake ( $A=75$ ha; $\bar{z}=13.9 \mathrm{~m} ; z_{\max }=36 \mathrm{~m}$ ). Harp Lake is located near Huntsville, Ontario at $79^{\circ} 08^{\prime} \mathrm{W}, 45^{\circ} 23^{\prime} \mathrm{N}$ and an altitude of $326 \mathrm{~m}$ above mean sea level. The open lake installation of the collector was intended to provide atmospheric loading data of more relevance to the lake than could be obtained with shore based collectors. The collector was installed slightly off the vertical $\left(2^{\circ}\right)$ to allow the water collected to drain to one corner where a rubber hose tap facilitated sampling. Wire mesh surrounded the collecting surface to deter birds. Observations by field personnel stationed at a nearby cottage on Harp Lake indicated that contamination by birds was unlikely.

The size of the collecting surface $\left(1 \mathrm{~m}^{2}\right.$ ) enabled rainfall to be gauged easily. Total rainfall was measured at the time of sampling and the collector was drained, rinsed and left uncovered after each collection. Analytical results of subsequent rainfalls therefore included dry fallout (dust, pollen, etc.) accumulating in the collector. In all, 32 collections 
of rainfall samples were analyzed from rainfalls occurring on Harp Lake between May 3 and August 23 of 1974. Sample volume was large enough on 23 of the collections to permit analysis of several subsamples after filtration through washed membrane filters and nylon mesh of pore sizes $0.22 \mu \mathrm{m}, 1.214 \mu \mathrm{m}, 77 \mu \mathrm{m}$ and $385 \mu \mathrm{m}$ in order to determine the size fraction of $\mathrm{N}$ and $\mathrm{P}$ in the samples.

Filtration through $385 \mu \mathrm{m}$ mesh was designed to exude airborne detritus of relatively large size (bark and leaf fragments from trees, etc.) which was not considered to be an important input yet might have contributed to random contamination of the water in the collector were it not filtered out. All samples were filtered at the Harp Lake field laboratory immediately after collection. The $\mathrm{pH}$ of 14 separate rainfall samples was determined with a Sargeant Welch Model PBL pH meter. Nutrient analyses of refrigerated precipitation samples were completed within a few days of collection according to Amer. Pub. Health Assoc. (1971), after adaptation for autoanalyzer use.

Weighted average $\mathrm{N}$ and $\mathrm{P}$ concentrations were calculated for each rainfall by determining concentration and rainfall volume between each sampling interval during the rainfall. When only one collection at the end of the rain was made, the concentration determined was considered the average value for the rainfall.

Dissolved and total $\mathrm{N}$ and $\mathrm{P}$ were also determined on melt from nine snow-ice samples and four fresh snow samples. (A mid-winter thaw resulted in partial melting of snow on the surface of the lake ice and when mixed with rain, subsequent freezing of the "slush" resulted in several $\mathrm{cm}$ of "snow-ice"). Atmospheric nutrient inputs during the winter were estimated by multiplying the total precipitation by the average concentration in the snow and snow-ice samples.

Total aeolian nutrient loading to Harp Lake was extrapolated to the annual period between June 20, 1973 and J une 20, 1974 (a time period when other components of the nutrient budget of this lake were measured) by employing records of daily precipitation kept at Huntsville, approximately $9 \mathrm{~km}$ southwest of Harp Lake. 


\section{RESULTS AND DI SCUSSI ON}

The $\mathrm{pH}$ of 14 of the rainfall samples collected between May 3 and August 23 of 1974, ranged from 3.2 to 5.1 with a median of 3.9. No seasonal trends were apparent. Such low values suggest industrial contamination of the atmosphere with oxides of nitrogen and sulphur as has been observed for other areas of Europe and North America (Likens and Borman 1974; Cogbill and Likens 1974; Anon. 1972; Barrett and Brodin 1955).

Samples taken from the collector at the end of a rainfall period were always lower in total P concentration than samples collected earlier during the rain. For example, the concentration of dissolved reactive $P$ in rainwater collected during the initial period of rainfall on May 27 was $0.053 \mathrm{mg} / \mathrm{L}$ but had decreased to $0.031 \mathrm{mg} / \mathrm{L}$ when sampled 1.25 hr later. This "washout effect" has been demonstrated in more detail by Gomolka (1975) who found as much as $23 \%$ of the $P$ loading in a rainstorm to fall within the first minute. On the other hand, nitrogen (both inorganic and total) increased as often as decreased during the rains monitored on Harp Lake. Concentrations of total $\mathrm{N}$ and total $\mathrm{P}$ ranged from 0.67 to $5.0 \mathrm{mg} \mathrm{N} / \mathrm{L}$ and from 0.01 to $0.54 \mathrm{mg} \mathrm{P} / \mathrm{L}$ in rainfall samples (Fig. 2) and were positively correlated $(p<0.01)$.

A positive correlation ( $p<0.01$ ) between ammonia- $\mathrm{N}$ and nitrate- $\mathrm{N}$ in rainfall samples was found (Fig. 3). The weighted average concentration of nitrate- N (0.73 mg/L) was nearly $70 \%$ higher than the weighted average ammonia- $N$ concentration of 0.44 $\mathrm{mg} / \mathrm{L}$ (Table 1 ).

The relative proportions of these two forms of nitrogen may be related to the $\mathrm{pH}$ of precipitation (Tabatabai and Laflen 1976). The acid rains over the northeastern United States also have nitrate- $\mathrm{N}$ as the most important form of nitrogen (Likens and Borman 1974). On the other hand, Tabatabai and Laflen (1976) found the proportions of ammonia- $\mathrm{N}$ and nitrate- $\mathrm{N}$ to be about equal in precipitation over Iowa, U.S.A. However, most of their recorded $\mathrm{pH}$ values were above 5.7 (the "neutral point" for atmospheric water, sensu, Barrett and Brodin 1955). Similarly, J unge (1958) found areas of the United

States having soils of low $\mathrm{pH}$ also received rainfall with low concentrations of ammonia- $\mathrm{N}$ 
and areas of more alkaline soils received higher concentrations of ammonia- $\mathrm{N}$ in rainfall.

Weighted mean concentrations of total $\mathrm{N}$ and total $\mathrm{P}$ during the spring and summer period of collection were $1.91 \mathrm{mg} \mathrm{N} / \mathrm{L}$ and $0.105 \mathrm{mg} \mathrm{P/L}$ (Table 1 ). Winter concentrations of total $\mathrm{N}$ were similar but total $\mathrm{P}$ concentrations averaging $0.018 \mathrm{mg} / \mathrm{L}$ in snow-ice and $0.013 \mathrm{mg} / \mathrm{L}$ in fresh snow (Table 2 ) were much lower than concentrations in precipitation during the ice-free period.

Some studies have distinguished between dry fallout of nutrients from the atmosphere and nutrients contributed in wet precipitation (Whitehead and Feth 1964; Kleusener 1972 (cited in Uttormark 1975); Gomolka 1975). In limnology, it is important to know what the significance of dry fallout is relative to its potential for effecting changes in lakewater concentrations of nutrients. Clearly, nutrient-bearing particles which enter lakewater from the atmosphere and which dissolve readily are likely to be ecologically more important than particles which do not dissolve readily. The size fractions of $\mathrm{N}$ and $P$ reported in Table 1 were determined after dry fallout in the collector was exposed to rainfall accumulations and therefore represent the portion of the dry fallout which is not readily soluble in rainwater. I deally, a better way to assess the significance of dry fallout might be to determine changes in dissolved $\mathrm{N}$ and $\mathrm{P}$ in a sample of sterile lake water exposed to dry fallout in a collector which could be covered during rainfall, and/or to monitor changes in microbiol biomass of a non-sterile lake water sample exposed in the same way.

At Harp Lake, particulate $\mathrm{N}(>0.22 \mu \mathrm{m}$ and $<385 \mu \mathrm{m})$ contributed only $10 \%$ of the total $\mathrm{N}$ input while dissolved inorganic $\mathrm{N}$ contributed $63 \%$ of the total. Of the total organic $\mathrm{N}$ in rainfall samples, $70 \%$ was dissolved (Table 1 ).

In $50 \%$ of the rainfall samples, total dissolved $\mathrm{P}(0.22 \mu \mathrm{m}$ filtrate $)$ comprised between $70 \%$ and $100 \%$ of the total $\mathrm{P}$ ( $385 \mu \mathrm{m}$ filtrate) during the spring and summer monitoring period (Figure 4 ). On the average, $52 \%$ of the weighted average total $P$ concentration was dissolved and $47 \%$ of the total dissolved $\mathrm{P}(<0.22 \mu \mathrm{m})$ was in dissolved reactive ("orthophosphate") form (Table 1 ). 
TABLE 1. Weighted average particle size of $N$ and $P$ in 28 sets of filtered rainfall samples (May 3 through August 23 , 1974.

\begin{tabular}{lccccc}
\hline & $<0.22 \mu \mathrm{m}^{*}$ & $<1.2 \mu \mathrm{m}$ & $<14 \mu \mathrm{m}$ & $<77 \mu \mathrm{m}$ \\
& & & $\mathrm{mg} / \mathrm{L}$ of rainfall & \\
\hline Total P & 0.055 & 0.057 & 0.058 & 0.076 & 0.105 \\
Total organic N & 0.52 & 0.54 & 0.63 & 0.63 & 1.80 \\
Total N & 1.69 & 1.71 & 1.80 & 1.91 \\
\hline
\end{tabular}

* Weighted average concentrations of dissolved, inorganic forms were:

ammonia- $\mathrm{N}, \quad 0.44 \mathrm{mg} / \mathrm{L}$; nitrite- $\mathrm{N}, 0.003 \mathrm{mg} / \mathrm{L} ;$ nitrate- $\mathrm{N}, 0.73 \mathrm{mg} / \mathrm{L} ;$ phosphorus, $0.026 \mathrm{mg} / \mathrm{L}$. 
TABLE 2. Nitrogen and phosphorus concentrations in frozen precipitation samples (January through March, 1974).

\begin{tabular}{lcccc}
\hline & \multicolumn{2}{c}{ Snow-Ice $(\mathrm{mg} / \mathrm{L})$} & \multicolumn{2}{c}{ Snow $(\mathrm{mg} / \mathrm{L})$} \\
\cline { 2 - 5 } & Range & Mean & $0.007-0.019$ & 0.013 \\
\hline Total P & $0.009-0.036$ & 0.018 & $0.004-0.012$ & 0.009 \\
Diss. reactive-P & $0.002-0.019$ & 0.008 & $0.26-0.48$ & 0.38 \\
Total Kjeldahl-N & $0.17-1.10$ & 0.49 & $0.08-0.38$ & 0.26 \\
Ammonia-N & $0.06-0.32$ & 0.14 & $0.001-0.004$ & 0.002 \\
Nitrite- $N$ & $0.002-0.007$ & 0.004 & $0.49-0.90$ & 0.70 \\
Nitrate- $N$ & $0.05-0.58$ & 0.19 & $0.75-1.37$ & 1.08 \\
Total N & $0.30-1.18$ & 0.68 &
\end{tabular}


Accumulations of pollen were particularly noticeable in the collector during the last week of May and influenced results of nutrient analyses of at least four samples. The correlation between total dissolved $\mathrm{P}$ and total $\mathrm{P}$ was increased somewhat when the four results were separated from the main body of the data (Figure 5). Microscopic examination of preserved samples showed a high density of birch pollen (20-30 $\mu \mathrm{m})$ with lesser amounts of pollen from ironwood? (35-42 $\mu \mathrm{m})$, balsam and spruce (60-130 $\mu \mathrm{m})$ and pine (40-60 $\mu \mathrm{m})$. In support of these findings, chemical results showed essentially all of the particulate $\mathrm{P}$ to be associated with the particles between 14 and $385 \mu \mathrm{m}$ in size (Table 1).

Snowfall ( $0.42 \mathrm{~m}$, water equivalent) was about $40 \%$ of the total annual precipitation in the Harp Lake area yet only $9 \%$ of the atmospheric total P loading and $23 \%$ of the total $\mathrm{N}$ loading was contributed during the ice-on period (Table 3 ). Barica and Armstrong (1971) have suggested that nutrient release with the thawing of ice is an important component of the nutrient budget of northwestern Ontario lakes. However, winter loadings of $\mathrm{N}$ and $\mathrm{P}$ from the atmosphere to Harp Lake are likely of even lesser significance than the above data indicate. The nutrients in ice and snow on the lake surface are released during the period of rapid runoff and lake flushing before major development of the phytoplankton takes place. Atmospheric loading during the ice-free period is a much more significant component of the annual loading since, in addition to being a greater input, it is supplied only to the surface waters of the lake during the period of thermal stratification and is therefore potentially more important for phytoplankton.

The total inorganic $\mathrm{N}$ loading of $1010 \mathrm{mg} / \mathrm{m}^{2} \cdot \mathrm{yr}$ to Harp Lake (Table 3 ) is considerably higher than the $250 \mathrm{mg} / \mathrm{m}^{2} \cdot \mathrm{yr}$ suggested for this area of Ontario by Uttormark (1975). He points out that some studies suggesting an annual input to the Great Lakes area of about $1000 \mathrm{mg} / \mathrm{m}^{2} \cdot \mathrm{yr}$ are probably more valid and, in fact, would be comparable with the Harp Lake data. Uttormark (1975) also suggests that there are long-term trends to increasing $\mathrm{N}$ loadings from the atmosphere so that many of the data collected several years ago may not indicate present day loadings. 
TABLE 3. Estimated atmospheric loading of $N$ and $P$ to Harp Lake (J une 20, 1973 to J une 21, 1974).

\begin{tabular}{|c|c|c|c|c|}
\hline & \multicolumn{3}{|c|}{ Specific loading $\left(\mathrm{mg} / \mathrm{m}^{2}\right)$} & $\begin{array}{c}\text { Annual Total Loading } \\
(\mathrm{kg}) \text { to Harp Lake }\end{array}$ \\
\hline Total P & 6.7 & 67.7 & 74.4 & 55.8 \\
\hline Total Dissolved P & $* 3.5$ & 35.5 & 39.0 & 29.2 \\
\hline Dissolved Reactive P & 3.8 & 16.8 & 20.6 & 15.4 \\
\hline Total Dissolved Organic-N & $* 100$ & 340 & 440 & 328 \\
\hline Total N & 370 & 1230 & 1600 & 1210 \\
\hline
\end{tabular}

* Total dissolved organic $\mathrm{N}$ and total dissolved $\mathrm{P}$ were not determined on snow melt, but estimates were made assuming similar ratios of these constituents to total $\mathrm{N}$ and total $\mathrm{P}$ as found in rainfall samples. 
Literature data on atmospheric loading of $P$ are even fewer; however, Dillon (1974) has estimated an annual total P loading of $77.2 \mathrm{mg} \mathrm{P} / \mathrm{m}^{2} \cdot y r$ to land based collection sites in the Haliburton Highlands region of Ontario and compares closely with the $74.4 \mathrm{mg}$ $\mathrm{P} / \mathrm{m}^{2} \cdot y r$ calculated from samples collected over the Harp Lake surface (Table 3). Also in Haliburton, Gomolka (1975) measured a total P aeolian loading of $37 \mathrm{mg} / \mathrm{m}^{2} \cdot y r$ to floating collectors on Lake St. Nora.

It is not readily apparent why the Lake St. Nora aeolian P loading value is so much lower than Dillon's (1974) and our Harp Lake values, although Lake St. Nora is much less influenced by dusty roads and highways than the other two sites. Despite the on-lake installation of our Harp Lake collector, it may not have been beyond the influence of the road circling Harp Lake. Further evidence to suggest that road dust might have contributed to high summertime aeolian P inputs to the Harp Lake collector is seen in the winter data (when the Harp Lake road was snow covered) which are very similar at Lake St. Nora and at Harp Lake $\left(8.4 \mathrm{mg} / \mathrm{m}^{2}\right.$ and $6.7 \mathrm{mg} / \mathrm{m}^{2}$ respectively).

By separating out the results (14-385 $\mu \mathrm{m}$ size range) on the four above mentioned samples containing visible amounts of pollen, it was determined that pollen contributed about $20 \%$ of the annual total $\mathrm{P}$ input from the atmosphere. On the other hand, nitrogen contributed in pollen was a much less significant portion of the total atmospheric $\mathrm{N}$ input because inorganic $\mathrm{N}$ was the dominant form of $\mathrm{N}$ in precipitation. Particulate $\mathrm{N}$ in the size range 14-385 $\mu \mathrm{m}$ in the four samples containing pollen contributed only $6.6 \%$ of the total annual atmospheric loading of nitrogen.

In view of the relationships which define lake trophic state as a function of $\mathrm{P}$ loading and P residence time (Vollenweider 1975, 1976), it is conceivable that shallow ponds with low hydraulic loads (ie those potholes on Ontario's Precambrian Shield with only intermittent inflows) could achieve eutrophic states resulting primarily from atmospheric inputs of nutrients. It is significant that a substantial portion of the total atmospheric nutrient load is in dissolved inorganic form and hence, readily available for aquatic plants and algae. 


\section{LITERATURE CITED}

AMER. PUB. HEALTH ASSOC. 1971. Standard Methods for the Examination of Water and Wastewater. $13^{\text {th }}$ Edition, Washington, D.C. 874 p.

ANON. 1972. Sulphur pollution across national boundaries. Ambio 1(1): 15-20.

BARICA, J. and F.A.J. ARMSTRONG. 1971. Contribution by snow to the nutrient budget of some small northwest Ontario lakes. Limnol. Oceanogr. 16 (6): 891-899.

BARRETT, E. and G. BRODIN. 1955. The acidity of Scandinavian precipitation. Tellus 7 (2): 251-257.

COGBILL, C.V. and G.E. LIKENS. 1974. Acid precipitation in the northeastern United States. Water Resources Research 10 (6): 1133-1137.

DILLON, P.J. 1974. The prediction of phosphorus and chlorophyll concentrations in lakes. Ph.D. Thesis, Dept. of Zoology, University of Toronto, Toronto, Ontario. 330 p.

DILLON, P.J. and F.H. RIGLER. 1975. A simple method for predicting the capacity of a lake for development based on lake trophic status. L. Fish. Res. Board Can. 32: 1519-1531.

GOMOLKA, R.E. 1975. An investigation of atmospheric phosphorus as a source of lake nutrient. M.Sc. Thesis, Dept. of Zoology, University of Toronto, Toronto, Ontario. $167 p$.

JUNGE, C.E. 1958. The distribution of ammonia and nitrate in rainwater over the United States. Trans. Am. Geophys. Union. 39: 241-248.

KLUESENER, J.W. 1972. (Cited in Uttormark, 1975). Nutrient transport and transformation in Lake Wingra, Wisconsin. Ph.D. Thesis, Water Chemistry Dept., Univ. Wisconsin, Madison, Wisconsin.

LIKENS, G.E. and F.H. BORMANN. 1974. Acid rain: a serious regional environmental problem. Science 184: 1176-1179.

NICHOLLS, K.H. 1976. Comparative limnology of Harp and J erry Lakes, adjacent cottaged and uncottaged lakes on southern Ontario's Precambrian Shield. Ontario Ministry of the Environment, Water Resources Branch, Toronto, Ontario. $87 \mathrm{p}$. 
TABATABAI, M.A. and J.M. LAFLEN. 1976. Nitrogen and sulfur content and $\mathrm{pH}$ of precipitation in lowa. L. Environ. Qual. 5(1): 108-112.

UTTORMARK, P.D. 1975. Atmospheric contributions of nitrogen and phosphorus. In "Estimating Nutrient Loadings of Lakes". Mimeographed MS. Water Resources Centre, Madison, Wisconsin. $32 \mathrm{p}$.

VOLLENWEIDER, R.A. 1975. Input-output models, with special reference to the phosphorus loading concept in limnology. Schweiz. Z. Hydrol. 37: 53-84.

1976. Advances in defining critical loading levels for phosphorus in lake eutrophication. Mem. $1^{\text {st }}$ Ital. Idrobiol., 33: 53-83.

WHITEHEAD, H.C. and J.H. FETH. 1964. Chemical character of rain, dry fallout and bulk precipitation at Menlo Park, California, 1957 - 1959. Geophys. Res. 69 (16): 3319-3333. 


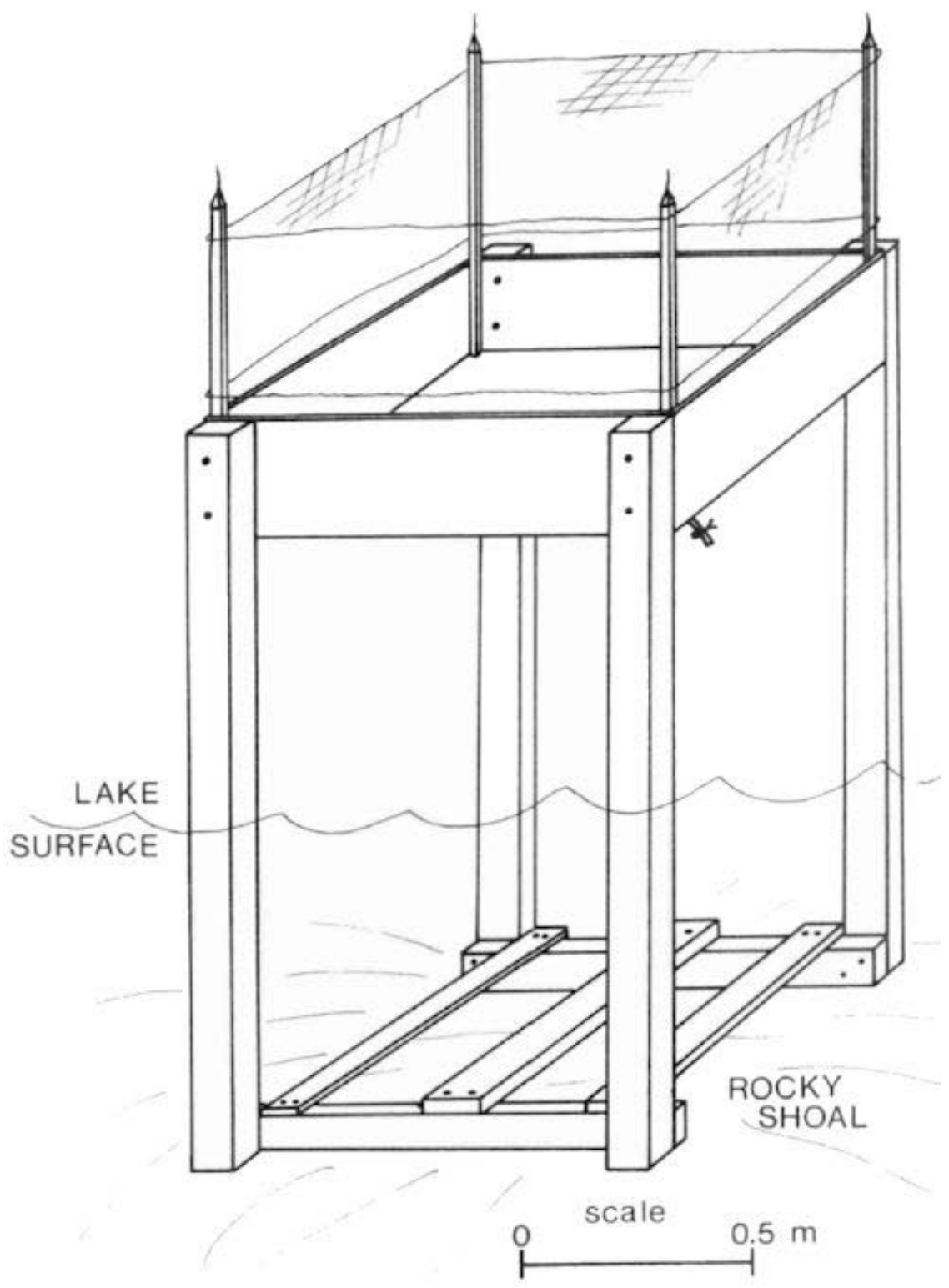

Fig. 1. The rainfall collector which was installed on a rocky shoal of Harp Lake. The collector was anchored in the shallow water overlying the shoal by several large rocks placed on the lower platform. 


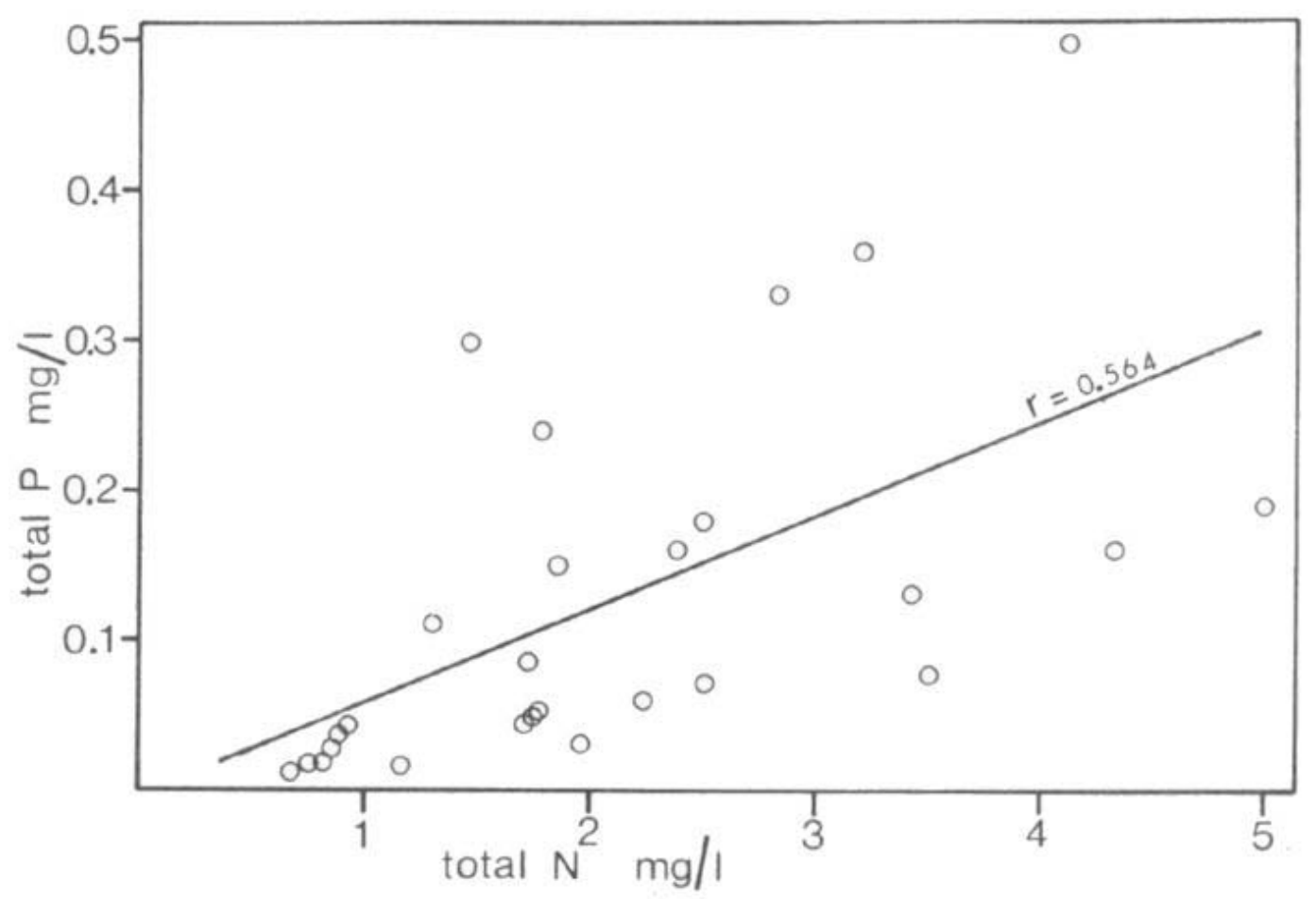

Fig. 2. Correlation between total $\mathrm{N}$ and total $\mathrm{P}(<385 \mu \mathrm{m})$ in rainfall samples collected between May 3 and August 23, 1974.

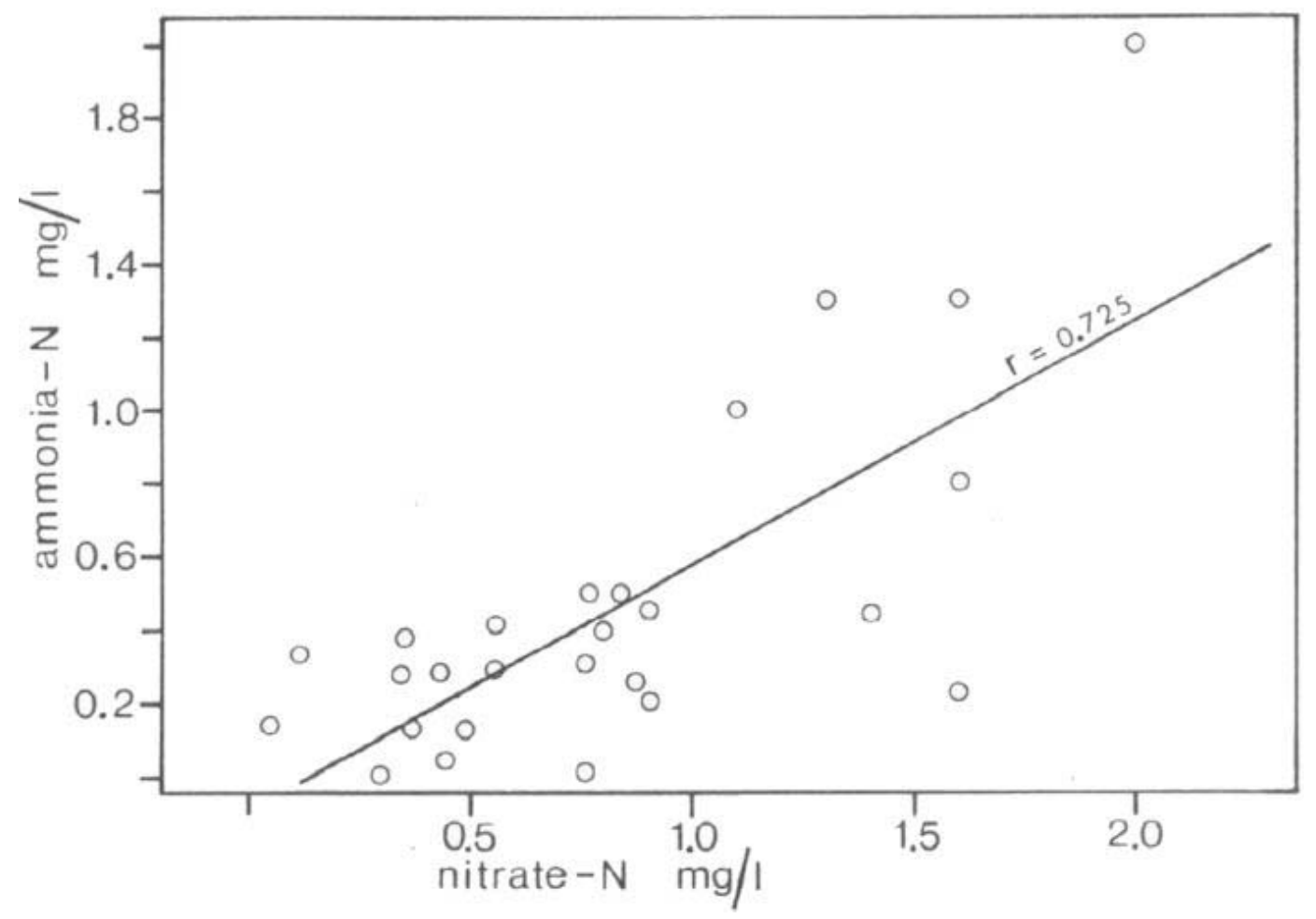

Fig. 3. Correlation between nitrate and ammonia nitrogen $(<22 \mu \mathrm{m})$ in rainfall samples collected between May 3 and August 23, 1974. 


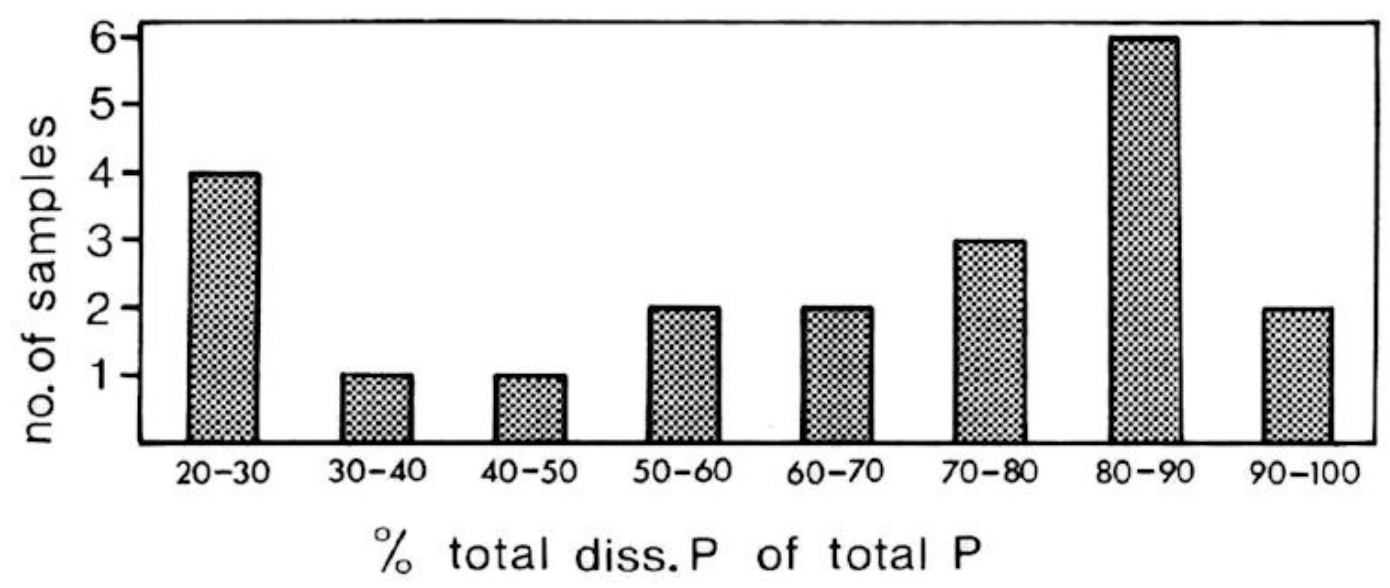

Fig. 4. Frequency distribution of the percentage of total $P(<385 \mu \mathrm{m})$ comprised of total dissolved $P(<0.22 \mu \mathrm{m})$ in rainfall samples collected on Harp Lake between May 3 and August 23, 1974.

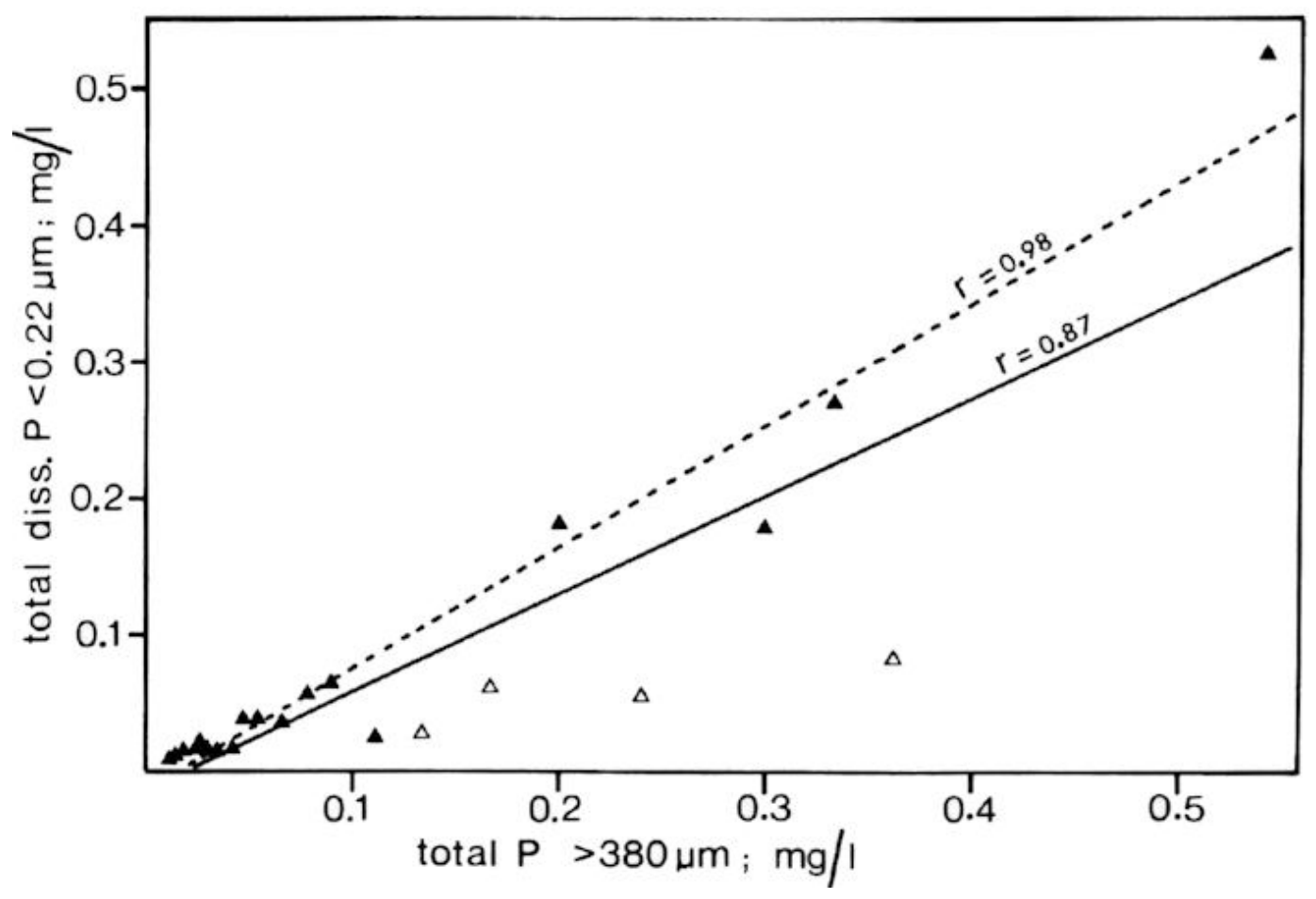

Fig. 5. Total $P(385 \mu \mathrm{m}$ filtrate) versus total dissolved $\mathrm{P}(0.22 \mu \mathrm{m}$ filtrate) in rainfall samples collected on Harp Lake. The correlation is improved when results from four samples containing visible amounts of pollen (open triangles) were excluded. 